\title{
PENERAPAN SIMULATOR ELECTRIC MIRROR UNTUK MENINGKATKAN KOMPETENSI DASAR MEMAHAMI SISTEM KELISTRIKAN PENGAMAN DAN KELENGKAPAN TAMBAHAN PADA PESERTA DIDIK DI SMKN
}

\author{
Herdy Puradimaja ${ }^{1}$, Mumu Komaro ${ }^{2}$, Tatang Permana ${ }^{3}$ \\ Universitas Pendidikan Indonesia \\ Jl. Dr. Setiabudi No. 229 Bandung 40154 \\ herdypuradimaja@gmail.com
}

\begin{abstract}
ABSTRAK
Penelitian ini bertujuan untuk mengetahui hasil belajar siswa dengan penerapan simulator electric mirror untuk meningkatkan kompetensi dasar memahami sistem kelistrikan pengaman dan kelengkapan tambahan pada peserta didik di SMKN 7 Baleendah. Penelitian ini menggunakan metode pra eksperimen dengan menggunakan desain penelitian one group pretest-posttest design. Populasi pada penelitian ini adalah kelas XI TKR SMK Negeri 7 Baleendah Tahun Ajaran 2017/2018 dengan jumlah siswa 180 orang. Pengambilan sampel dengan menggunakan purposive sampling dengan jumlah 32. Hasil penelitian menunjukkan pembelajaran dengan penerapan simulator electric mirror didapat $97 \%$ siswa masuk dalam kategori tuntas. Penggunaan alat perga simulator electric mirror dapat meningkatkan hasil belajar siswa dengan peningkatan hasil belajar $(\mathrm{N}-$ gain) dengan nilai 0,6 yang termasuk dalam kriteria sedang.
\end{abstract}

Kata kunci: electric mirror, media pembelajaran, hasil belajar, sistem kelistrikan

\section{PENDAHULUAN}

Pembelajaran merupakan suatu kegiatan yang melibatkan seseorang dalam upaya memperoleh pengetahuan, keterampilan dan nilai-nilai positif dengan memanfaatkan berbagai sumber untuk belajar (Kuswana, 2011). Proses pembelajaran dapat menjadi tolak ukur keberhasilan seorang siswa bila hasil dari proses pembelajaran yang sudah dilaksanakan di sekolah menunjukkan nilai yang lebih tinggi dari pada standar yang telah ditetapkan sekolah.

SMK Negeri 7 Baleendah merupakan lembaga pendidikan formal yang bertujuan untuk mempersiapkan sumber daya manusia (SDM) yang memiliki kompetensi melalui program studi kejuruan yang ditawarkan. Program studi yang ditawarkan di SMK Negeri 7 Baleendah diantaranya adalah paket keahlian Teknik Kendaraan Ringan (TKR). Program Keahlian TKR siswa harus menguasai semua bidang pelajaran keahlian maupun pelajaran umum seperti pelajaran pemeliharaan kelistrikan kendaraan ringan (Sutrisno dan Siswanto, 2016). Mata pelajaran PKKR memiliki kompetensi dasar diantaranya yaitu 3.1 memahami sistem kelistrikan, pengaman, dan kelengkapan tambahan dan 4.1 memelihara sistem kelistrikan, pengaman, dan kelengkapan tambahan Sesuai Operasional Prosedur (SOP).

\footnotetext{
${ }^{1}$ Mahasiswa Departemen Pendidikan Teknik Mesin FPTK UPI

2 Dosen Departemen Pendidikan Teknik Mesin FPTK UPI

${ }^{3}$ Dosen Departemen Pendidikan Teknik Mesin FPTK UPI
} 
Hasil observasi dan wawancara di SMK Negeri 7 Baleendah diketahui bahwa proses pembelajaran yang dilakukan pada kompetensi dasar memahami sistem kelistrikan, pengaman dan kelengkapan tambahan dominan menggunakan metode ceramah. Pemahaman siswa tidak dapat maksimal karena siswa kurang partisipatif selama proses pembelajaran dan pembelajaran masih berfokus kepada guru (teacher center) tanpa adanya proses belajar yang berlangsung secara dua arah (Munir, 2010). Hal tersebut juga menyebabkan siswa menjadi kurang tertarik dalam mengikuti pembelajaran karena KBM cenderung monoton dan membosankan. Kondisi tersebut menunjukkan bahwa proses pembelajaran belum mampu mendorong siswa untuk mencapai tujuan pembelajaran. Tujuan yang diharapkan dalam pembelajaran adalah terserapnya materi pembelajaran secara optimal oleh siswa (Sumantri, 2015).

Hasil belajar yang dicapai dengan hanya menggunakan metode pembelajaran ceramah. Kondisi ini terlihat dari banyaknya siswa yang kurang memahami materi yang diajarkan (Roestiyah, 2008). Indikatornya adalah rendahnya hasil belajar siswa. Hasil yang dicapai siswa dalam kompetensi memahami sistem kelistrikan electric mirror menunjukkan $43 \%$ siswa mendapatkan nilai di bawah Kriteria Ketuntasan Minimal (KKM) yaitu kurang dari 75.

Penggunaan metode pembelajaran dan media pembelajaran adalah salah satu hal yang bisa dilakukan dalam upaya peningkatan hasil belajar. Proses pembelajaran dapat efektif apabila ada dua unsur yang saling berkaitan yaitu metode mengajar dan media pembelajaran (Arsyad, 2014). Media pembelajaran dan metode mengajar yang bisa diterapkan di SMK adalah dengan penggunaan media yang bisa diperagakan oleh guru dan siswa dengan menggunakan metode demonstrasi. Ketersediaan media adalah hal penting yang harus dimiliki sekolah. Media pembelajaran yang kurang dimiliki oleh sekolah akan berpengaruh pada kualitas hasil belajar karena pada hakikatnya media pembelajaran dapat digunakan sebagai pengantar pesan yang efektif dari sumber belajar ke siswa (Sanjaya, 2011).

Penggunaan media dalam wujud yang sebenarnya dapat membuat pemahaman siswa menjadi tidak abstrak (Wibawa dan Mukti, 2002). Media sederhana tiga dimensi memiliki kelebihan-kelebihan: memberikan pengalaman secara langsung, penyajian secara konkret dan menghindari verbalisme, dapat menunjukkan objek secara utuh baik konstruksi dan cara kerjanya, dan dapat menunjukkan alur suatu proses secara jelas (Daryanto, 2016).

Simulator electric mirror sebagai media pembelajaran berupa benda sebenarnya (tiga dimensi) pada kompetensi memahami sistem kelistrikan electric mirror. Pelaksanaan pembelajaran dengan menggunakan media simulator electric mirror dapat membuat setiap 
siswa dapat mengetahui bagaimana proses kerja, fungsi, dan gerakan dari tiap-tiap komponen dari motor listrik, serta memberikan pemahaman mengenai rangkaian kelistrikan sistem electric mirror (Suyanto, 2013). Media pembelajaran electric mirror dapat membuat siswa lebih mudah untuk melakukan observasi mengenai apa yang dipelajari dan memberikan hasil belajar pada tingkat pemahaman pada siswa karena siswa tidak akan membayangkan suatu proses kerja yang abstrak yang terjadi di dalam sistem kelistrikan (Kristanto, 2013). Penggunaan media electric mirror membuat siswa mengalami pengalaman langsung, sehingga siswa bisa mendemonstrasikan bagaimana kerja suatu motor listrik.

\section{METODE PENELITIAN}

Metode penelitian yang digunakan adalah metode deskriptif. Populasi pada penelitian ini adalah siswa kelas XI Paket Keahlian Teknik Kendaraan Ringan SMK Negeri 7 Baleendah Tahun Ajaran 2017/2018. Subjek penelitian sebanyak 180 orang kelas XI TKR. Pengambilan sampel dengan menggunakan purposive sampling sebanyak 32 orang.

Instrumen yang digunakan yaitu tes tulis pilihan ganda. Tes dilakukan melalui dua tahap yaitu tes sebelum (pretest) dan sesudah diberikan treatment (posttest). Analisis data yang digunakan untuk hasil penilaian tes adalah dengan statistik deskriptif. Selanjutnya untuk mengetahui peningkatan hasil belajar yaitu dihitung menggunakan Normalized Gain (N-gain).

\section{HASIL PENELITIAN}

Hasil uji normalitas dengan program SPSS 24 menggunakan metode Shapiro-Wilk. Nilai sig. $(p$-value $)>0,05$ berarti data berdistribusi normal. Uji hipotesis dilakukan untuk membuktikan hipotesis penelitian hasilnya menunjukkan bahwa terdapat peningkatan pemahaman siswa terhadap hasil belajar pada pembelajaran kompetensi dasar memahami sistem kelistriktrikan pengaman dan kelengkapan tambahan.

Hasil yang didapat pada pretest berdasarkan temuan menunjukkan hasil belajar yang masih berada di bawah standar ketuntasan minimal yaitu $<75$. Sebanyak 32 siswa rata-rata nilai pretest masuk dalam kategori $\mathrm{D}$ dan nilai rata-rata hasil data posttest masuk dalam kategori B. Proses pembelajaran dengan penerapan media engine cutting diperoleh ketuntasan belajar siswa mencapai $97 \%$.

Pembelajaran sistem electric mirror pada kompetensi dasar memahami sistem kelistrikan pengaman dan kelengkapan tambahan dengan menggunakan alat peraga 
simulator electric mirror, berdasarkan nilai rata-rata $\mathrm{N}$-Gain pada kelas eksperimen adalah sebesar 0,6 termasuk dalam kategori sedang.

\section{PEMBAHASAN}

Pembelajaran dengan menggunakan alat peraga simulator electric mirror yang dilakukan di ruangan praktikum Program Studi TKR SMK Negeri 7 Baleendah. Pembelajaran dilakukan dengan cara menerangkan materi tentang electric mirror menggunakan power point dan alat peraga simulator electric mirror yang sudah disiapkan, setelah itu guru membagi jumlah siswa dalam 5 kelompok dan membagikan job sheet untuk dimengerti dan dipahami oleh siswa.

Guru memberikan demonstrasi cara memasang rangkaian kelistrikan pada electric mirror. Siswa memperhatikan guru dan satu persatu setiap kelompok maju ke depan untuk mempraktekan cara memasang kabel-kabel pada kelistrikan electric mirror mulai dari memasang kabel ke baterai dalam kondisi kunci kontak off (Muryanto, 2013). Kemudian menghubungkan setiap terminal menggunakan kabel-kabel seperti menghubungkan fuse ke kunci kontak. Dari kunci kontak dihubungkan ke switch mirror menggunakan kabel yang sama tetapi harus mengetahui mana yang dialiri arus dan mana yang dialiri massa. Selanjutnya dari switch mirror terdapat 10 terminal yang harus dihubungkan ke motor listrik spion kanan dan motor listrik spion kiri. Semua siswa aktif dan mampu menyerap lebih banyak materi (Kurniawan, dan Mujahid, 2015). Setelah mereka melihat langsung komponen-komponen dan cara kerja dari electric mirror pada alat peraga. Media alat peraga siswa tidak hanya berimajinasi tetapi mereka dapat mengetahui secara langsung.

Simulator electric mirror yang digunakan dapat mempermudah guru dalam menyampaikan materi atau pesan kepada siswa. Melibatkan siswa untuk bisa langsung berinteraksi dengan objek, sehingga siswa lebih mudah dalam memahami materi atau pesan yang disampaikan oleh guru. Menggunakan alat peraga ini guru dapat terbantu dalam menyampaikannya suatu materi atau pelajaran yang akan disampaikan kepada peserta didik (Sjukur, 2012).

Media pembelajaran alat peraga simulator electric mirror mampu membuat siswa lebih aktif, lebih senang dalam belajar karena lebih mudah diserap pembelajarannya. Dengan adanya alat peraga, siswa akan lebih banyak mengikuti pelajaran dengan gembira, sehingga minatnya dalam mempelajari semakin besar (Sadiman, 2007). Siswa senang, terangsang, kemudian tertarik dan bersikap positif terhadap pembelajaran. 
Hasil penelitian menunjukkan adanya peningkatan pemahaman siswa terhadap hasil belajar yaitu sebesar 97\%. Hal ini dapat diketahui dari peningkatan nilai rata-rata pretest yaitu 57 dan nilai rata-rata posttest yaitu 83. Hasil nilai tersebut signifikan peningkatan pemahaman siswa terhadap hasil belajar pada nilai rata-rata $\mathrm{N}$-Gain berada dalam kategori sedang yaitu 0,6. Selain itu, uji hipotesis penelitian yang dilakukan menunjukkan adanya peningkatan pemahaman terhadap hasil belajar (Prasetyawan, 2013).

\section{KESIMPULAN}

Penelitian ini dapat disimpulkan bahwa: pembelajaran menggunakan simulator electric mirror membuat siswa mampu menyerap materi lebih baik, menjadi aktif dan mampu memahami materi pada saat pembelajaran berlangsung. Alat peraga membuat siswa dapat melihat secara langsung komponen-komponen dan cara kerjanya. Hasil belajar dengan menggunakan alat peraga simulator electric mirror menunjukkan adanya peningkatan hasil belajar siswa dan telah mencapai Kriteria Ketuntasan Minimal. Peningkatan pemahaman siswa terhadap hasil belajar masuk dalam kategori sedang.

\section{REFERENSI}

Arsyad, A. (2014). Media Pembelajaran. Jakarta: PT. Raja Grafindo Persada.

Daryanto. (2016). Media Pembelajaran. Yogyakarta: Gava Media.

Kristanto, R. D. (2013). Pengembangan Media Pembelajaran Praktikum Kelistrikan Body Otomotif Untuk Meningkatkan Kualitas Pembelajaran Mahasiswa D3 Teknik Mesin Unesa. Jurnal Pendidikan Vokasi, 1(3), 2.

Kurniawan, A., dan Mujahid, A. (2015). Pengembangan Media Pembelajaran Alat Peraga Pada Sistem Starter Mobil untuk Meningkatkan Hasil Belajar Siswa di SMK Cipta Karya Prembun. Jurnal Pendidikan Teknik Otomotif, 5(1), 15.

Kuswana, W. S. (2011). Taksonomi Berpikir. Bandung: PT. Remaja Rosdakarya.

Munir. (2010). Kurikulum Berbasis Teknologi Informasi dan Komunikasi. Bandung: Alfabeta.

Muryanto. (2013). Peningkatan Pemahaman Troubleshooting Kelistrikan Engine PGM-Fi dengan Alat Peraga Kelistrikan Engine. Jurnal Pendidikan Teknik Mesin, 1(2), 72.

Prasetyawan, H. (2013). Meningkatkan Hasil Belajar Kompetensi Permesinan Mata Pelajaran Dasar Kompetensi Kejuruan Siswa Kelas X Menggunakan Media Audio Visual. Jurnal Pendidikan Teknik Mesin, 13(1),29. 
Roestiyah. (2008). Strategi Belajar Mengajar. Jakarta: Rineka Cipta.

Sadiman. (2007). Media Pendidikan. Jakarta: PT Raja Grafindo Persada

Sanjaya, W. (2011). Perencanaan dan Desain Sistem Pembelajaran. Jakarta: Kencana.

Sjukur, S. B. (2012). Pengaruh Blended Learning terhadap Motivasi Belajar dan Hasil Belajar Siswa Tingkat SMK. Jurnal Pendidikan Vokasi, 2(3), 24.

Sumantri, S. (2015). Strategi Pembelajaran. Jakarta: Rajawali Pers.

Suyanto, W. (2013). Penggunaan EFI Scanner Sebagai Media Pembelajaran Untuk Meningkatkan Minat, Motivasi, dan Prestasi Belajar Siswa. Jurnal Pendidikan Vokasi, 3(2), 192.

Sutrisno, P. dan Siswanto, B. (2016). Faktor-Faktor yang Mempengaruhi Hasil Belajar Siswa pada Pembelajaran Praktik Kelistrikan Otomotif SMK di Kota Yogyakarta. Jurnal Pendidikan Vokasi. 6(1), 114.

Wibawa, B. dan Mukti, F. (2002). Media Pengajaran. Jakarta: Depdikbud Dirjen Dikti. 